\title{
Penerapan Model Inkuiri Terbimbing Untuk Meningkatkan Kemampuan Berpikir Kritis Dan Sikap Ilmiah Siswa Dalam Pembelajaran IPA Siswa Kelas V SDN 9 Bengkulu Tengah
}

\section{Julimah}

Program Magister Pendidikan Dasar Universitas Bengkulu.

\section{Endang Widi winarni}

Program Magister Pendidikan Dasar Universitas Bengkulu.

\section{Daimun Hambali}

Program Magister Pendidikan Dasar Universitas Bengkulu.

\begin{abstract}
Penelitian ini bertujuan untuk meningkatkan aktivitas, kemampuan berpikir kritis, dan sikap ilmiah siswa pembelajaran IPA melalui model inkuiri terbimbing di kelas V SDN 9 Bengkulu Tengah. Penelitian yang dilakukan adalah penelitian tindakan kelas (Classroom action research) sebanyak 3 siklus. Instrumen yang digunakan yaitu lembar observasi aktivitas pembelajaran, tes kemampuan berpikir kritis, dan lembar observasi sikap ilmiah. Hasil yang dicapai dalam penelitian ini yaitu: (1) aktivitas pembelajaran siklus I sebesar $63,64 \%$ dengan kategori Cukup, siklus II sebesar77,27\% dengan kategori Baik, dan siklus III sebesar 90,91\% dengan kriteria Sangat Baik; (2) kemampuan berpikir kritis untuk indikator memfokuskan pertanyaan siklus I sebesar 76,25\%, siklus II sebesar 86,25\%, dan siklus III sebesar 95\%, indikator menjelaskan secara sederhana siklus I sebesar 58,33\%, siklus II sebesar $72,50 \%$, dan siklus III sebesar 76,67\%, indikator membangun keterampilan dasar siklus I sebesar $60 \%$, siklus II sebesar $81,67 \%$, dan siklus III sebesar 88,33\%, indikator menyimpulkan siklus I sebesar $91,25 \%$, siklus II sebesar 97,50\%, dan siklus III sebesar 100\%; (3) sikap ilmiah siklus I untuk indikator rasa ingin tahu yang tinggi
\end{abstract}


sebesar 76,20\%, siklus II sebesar 79,30\%, dan siklus III sebesar $82,95 \%$ siklus I untuk indikator ulet dan tidak putus asa siklus I sebesar 76,45\%, siklus II sebesar 79,40\%, dan siklus III sebesar 83,80\%, indikator kreatif siklus I sebesar $72,85 \%$, siklus II sebesar 77,05\%, dan pada siklus III sebesar $82,95 \%$. Berdasarkan hasil penelitian dapat disimpulkan bahwa penerapan model inkuiri terbimbing dapat meningkatkan kemampuan berpikir kritis dan sikap ilmiah siswa Kelas V SDN 9 Bengkulu Tengah.

Kata Kunci: Model Inkuiri Terbimbing, Aktivitas Pembelajaran, Kemampuan Berpikir Kritis, dan Sikap Ilmiah.

\section{Pendahuluan}

Perkembangan ilmu pengetahuan dan teknologi yang sangat pesat membawa perubahan di berbagai aspek kehidupan menuntut manusia untuk hidup lebih baik dan mengadakan pembangunan di segala bidang, terutama dalam bidang pendidikan. Terkait dengan perkembangan teknologi tersebut berdampak terhadap pengajaran di sekolah khususnya sekolah dasar (SD). Upaya meningkatkan mutu pendidikan memerlukan pembenahan semua aspek yang terkait dalam penyelenggaraan pendidikan diantaranya perbaikan kurikulum, hubungan sekolah dengan lingkungan dan pemerintah, perencanaan dan pengembangan manajerial sekolah, pemberdayaan guru, inovasi model, dan metode pembelajaran khususnya pada mata pelajaran IPA (Ilmu Pengetahuan Alam).

IPA merupakan suatu ilmu pengetahuan yang berperan penting dalam kehidupan karena menjadi dasar pengembangan teknologi yang membuka kesempatan untuk memupuk rasa ingin tahu anak didik secara alamiah, memecahkan masalah yang dihadapi sehingga bisa merangsang siswa untuk berpikir kritis yang kelak bisa digunakan untuk menjawab tantangan zaman.

Pelaksanaan pembelajaran khususnya di SDN 9 Bengkulu Tengah pada mata pelajaran IPA, siswa kelas $\mathrm{V}$ masihcenderung pasif dalam pembelajaran, interaksi guru dan siswa relatif minim, pembelajaran yang digunakan teacher centre, guru belum optimal dalam mengarahkan dan melatih kemampuan berpikir kritis siswa, nilai siswa $60 \%$ masih di bawah kriteria ketuntasan minimal, siswa jarang diberikan kesempatan untuk memecahkan masalah sendiri, penyampaian konsep kepada siswa dalam kegiatan pembelajaran tanpa melalui proses ilmiah, yang pada dasarnya dapat dikembangkan dan dilatih dalam proses pembelajaran IPA.

Maka dari itu di perlukan suatu inovasi pembelajaran yang inovatif yaitu berupa penerapan model pembelajaran yang dapat membangkitkan motivasi siswa untuk berpikir kritis dan bersikap ilmiah. Hal tersebut selaras dengan model pembelajaran inkuiri. Untuk mencapai tujuan yang diharapkan dalam proses pembelajaran IPA, keaktifan siswa dalam kegiatan pembelajaran dapat direalisasikan oleh guru dengan kegiatan percobaan dengan berbantukan LKS (Lembar Kerja Siswa). 


\section{Penerapan Model Inkuiri Terbimbing Untuk Meningkatkan Kemampuan Berpikir Kritis Dan Sikap Ilmiah Siswa Dalam Pembelajaran IPA Siswa Kelas V SDN 9 Bengkulu Tengah}

Berdasarkan permasalahan di atas, peneliti mencoba solusi untuk perbaikan dan peningkatan pembelajaran di kelas $\mathrm{V}$ dengan menerapkan model pembelajaran inkuiri terbimbing dipilihnya model inkuiri terbimbing ini memiliki beberapa kelebihan antara lain: (1) dapat mengembangkan self concept pada siswa sehingga siswa dapat mengerti konsep dasar dan ide-ide yang lebih baik; (2) membantu menggunakan ingatan dan transfer pada situasi proses belajar yang baru; (3) mendorong siswa untuk berpikir dan bekerja atas inisiatifnya sendiri, bersikap objektif, jujur, dan terbuka; (4) mendorong siswa untuk berpikir kritis dan merumuskan hipotesanya sendiri; (5) memberikan kepuasaan secara intrinsik; (6) situasi proses belajar lebih termotivasi; (7) dapat mengembangkan bakat atau kecakapan hidup; (8) memberikan kebebasan siswa untuk belajar sendiri; (9) dapat menghindari siswa dari cara-cara belajar yang tradisional; dan (10) dapat memberikan waktu kepada siswa secukupnya sehingga mereka bisa mengasimilasi dan mengakomodasi informasi (Sofiani, 2011: 18).

Selanjutnya Samatowa (2016: 2) mengemukakan bahwa pembelajaran IPA di SD hendaknya membuka kesempatan untuk memupuk rasa ingin tahu anak didik secara alamiah. Hal ini akan membantu mereka mengembangkan kemampuan bertanya dan mencari jawaban atas berdasarkan bukti serta mengembangkan cara berpikir ilmiah. Pembelajaran IPA di SD hendaknya ditujukan untuk memupuk minat dan pengembangan siswa. Untuk mencapai tujuan dan memenuhi pendidikan IPA itu, pendekatan yang digunakan dalam proses belajar mengajar IPA salah satunya menggunakan pendekatan Inquiry (penyelidikan).

Dari beberapa penelitian ini disimpulkan bahwa dalam Proses pembelajaran IPA yang dapat memberikan pengalaman langsung pada siswa untuk menumbuhkan kemampuan berpikir kritis, bekerja dan bersikap ilmiah serta mengkomunikasikannya sebagai aspek penting kecakapan hidup. Maka peneliti tertarik melakukan penelitian lebih dalam dengan judul "Penerapan Model Inkuiri Terbimbing Untuk Meningkatkan Kemampuan Berpikir Kritis dan Sikap Ilmiah

Siswa Dalam Pembelajaran IPA Siswa Kelas V SDN 9 Bengkulu Tengah”. Dengan menerapkan model inkuiri terbimbing ini siswa di dalam pembelajaran diharapkan secara maksimal terlibat langsung dalam proses kegiatan belajar, sehingga dapat meningkatkan kemampuan siswa dalam berpikir yang akhirnya mampu berpikir kritis dan mengembangkan sikap ilmiah yang dimiliki oleh siswa tersebut.

Berdasarkan latar belakang masalah di atas, maka rumusan masalah pada penelitian ini sebagai berikut:

1. Bagaimanakah penerapan model pembelajaran inkuiri terbimbing dapat meningkatkan aktivitas pembelajaran IPA di kelas V SDN 9 Bengkulu Tengah?

2. Apakah penerapan model pemelajaran inkuiri terbimbing dapat meningkatkan kemampuan berpikir kritis siswa kelas V SDN 9 Bengkulu Tengah? 
3. Apakah penerapan model pembelajaran inkuiri terbimbing dapat meningkatkan sikap ilmiah siswa kelas V SDN 9 Bengkulu Tengah?

Berdasarkan rumusan masalah di atas, maka tujuan pada penelitian ini sebagai berikut: Mendeskripsikan penerapan model pembelajaran inkuiri terbimbing sehingga dapat meningkatkan aktivitas pembelajaran, kemampuan berpikir kritis, dan sikap ilmiah siswa pada pembelajaran IPA di kelas V SDN 9 Bengkulu Tengah. Manfaat hasil penelitian ini adalah sebagai berikut:

1. Bagi siswa, dapat meningkatkan keaktifan siswa dalam pembelajaran sehingga lebih mengerti dan memahami materi yang diajarkan. Dengan demikian siswa dapat mengembangkan berpikir kritis dan bersikap ilmiah.

2. Bagi guru, dapat mengembangkan model pembelajaran yang bervariasi sesuai dengan karakteristik pemelajaran dan karakteristik peserta didik. Menambah pengetahuan dan keterampilan dalam mengelolah pembelajaran sehingga bisa membangkitkan rasa percaya diri sehingga lebih bersemangat untuk memperbaiki pembelajarannya secara terus menerus.

3. Bagi pengelola sekolah, membantu sekolah dalam mengembangkan dan menciptakan lembaga pendidikan berkualitas yang akan menjadi percontohan atau model bagi sekolah-sekolah, disamping itu akan terlahir guru yang profesional berpengalaman dan menjadi kepercayaan orang tua masyarakat serta pemerintah. Penelitian tindakan kelas ini bermanfaat bagi guru yang mau memperbaiki pembelajarannya terutama pada pelajaran IPA dengan penerapan model pembelajaran inkuiri terbimbing dengan pendekatan saintifik untuk meningkatkan kemampuan berpikir kritis dan sikap ilmiah siswa.

4. Bagi peneliti, memberikan wawasan kepada peneliti dan sebagai acuan bagi penelitian lain dalam penelitian sejenis tentang Model Inkuiri terbimbing, kemampuan Berpikir kritis, dan Sikap ilmiah.

\section{Metode}

Jenis penelitian ini adalah Penelitian Tindakan Kelas (Classroom Action Research). Penelitian ini merupakan salah satu strategi bagi guru untuk memperbaiki layanan kependidikan yang harus diselenggarakan dalam konteks pembelajaran dikelasdan peningkatan program sekolah secara keseluruhan. (Sumadayo, 2013: 22). Dalam penelitian tindakan kelas terdiri dari empat tahapan kegiatan yaitu Perencanaan (planning), Tindakan (action), observasi (observation), serta refleksi (reflection) yang terdiri dari 3 siklusPenelitian ini dilakukan di SDN 9 Bengkulu Tengah dengan subjek penelitian adalah 20 orang siswa yang terdiri dari 7 laki-laki dan13 perempuan. Penelitian iniakan dilaksanakan pada semester genap tahun ajaran 2017/2018.

\section{Instrumen}

Instrumen yang digunakan adalah (1) lembar observasi aktivitas pembelajaran yang terdiri dari lembar observasi guru dan siswa. (2) Lembar Observasi sikap ilmiah meliputi lembar observasi sikap ilmiah siswa selama mengikuti pembelajaran yang sesuai dengan model pembelajaran inkuiri terbimbing. dan (3) lembar penilaian 


\section{Penerapan Model Inkuiri Terbimbing Untuk Meningkatkan Kemampuan Berpikir Kritis Dan Sikap Ilmiah Siswa Dalam Pembelajaran IPA Siswa Kelas V SDN 9 Bengkulu Tengah}

kemampuan berpikir kritis adalah lembar tes tertulis berupa soal essay sebanyak 4 soal yang digunakan post test. Setiap soal essay mempunyai skor yang berbeda-beda sesuai dengan bobot soal dan level berpikir kritis yang toatal nilai menjadi 100 .

\section{Teknik Pengumpulan Data}

Teknik pengumpulan data yang digunakan pada penelitian ini adalah (1) teknik observasi; (2) tes tertulis berupa soal essay untuk mengukur kemampuan berpikir kritis; dan (3) dokumentasi foto-foto waktu pembelajaran berlangsung.

\section{Hasil}

Berdasarkan hasil observasi terhadap aktivitas pembelajaran yang dilakukan oleh dua orang pengamat menunjukkan persentase skor pada siklus I sebesar $63,64 \%$ dengan kategori Cukup, pada siklus II sebesar 77,27\% dengan kategori Baik, pada siklus I sebesar 90,91\% dengan kategori Sangat Baik.

\section{Pembahasan}

Hasil penelitian dengan menerapkan model inkuiri terbimbing ditinjau dari kegiatan siklus I sampai pada kegiatan siklus III menunjukkan adanya peningkatan dalam aktivitas pembelajaran. Hal ini berdasarkan dari analisis data observasi keterlaksanaan terhadap aktivitas pembelajaran siklus I, siklus II, dan siklus III yang dilakukan dalam penelitian yaitu:

Pertama fase orientasi, guru memberikan motivasi kepada siswa untuk fokus menghadapi persoalan penting dan tingkat penguasaan yang diharapkan dengan memberi pertanyaan untuk menggali pengetahuan awal siswa dengan diberikan stimulasi siswa dapat termotivasi dalam belajar. Sejalan dengan hasil penelitian Winarni, dkk (2018: 72) menunjukkan bahwa dengan stimulasi, siswa dihadapkan pada sesuatu yang dapat menimbulkan tanda tanya kemudian melanjutkannya namun tidak memberikan generalisasi untuk meningkatkan keinginan untuk menyelidikinya sendiri.

Kemudian, siswa menanggapi dengan menjawab pertanyaan dari guru dan mendengarkan penjelasan materi pelajaran yang diberikan guru. Kegiatan yang dilakukan adalah guru mengajukan pertanyaan yang merangsang siswa untuk berani menjawab dan berpendapat tentang pertanyaan yang diajukan, hal ini dilakukan agar guru mengetahui pengetahuan awal yang dimiliki oleh siswa. Sejalan dengan pendapat Winarni (2012: 25) menjelaskan bahwa model pembelajaran berbasis penemuan dapat dicapai melalui: (a) pertanyaan-pertanyaan untuk mengungkap pengalaman dan pengetahuan; (b) pertanyaan-pertanyaan yang merangsang siswa menghubungkan informasi-informasi baru dengan konsep dan pengalaman yang sudah dimiliki; dan (c) pertanyaan yang mendorong siswa memahami dan mencapai tujuan. Hal ini diperkuat dengan hasil penelitian Swartaya, dkk (2013: 166) menyimpulkan bahwa karakteristik model perangkat pembelajaran yang dikembangkan memiliki ciri-ciri menggali pengetahuan siswa dengan menggunakan model inkuiri terbimbing berefleksi efektif, praktis, dan dapat meningkatkan keterampilan proses siswa dan pemahaman konsep siswa. 
Kedua fase eksplorasi, pada tahap ini siswa dibentuk ke dalam kelompok secara heterogen, guru membagikan LKS dan menjelaskan langkah-langkah dalam mengerjakan LKS kepada setiap kelompok. Hal ini sejalan dengan Trianto (2010: 42) yang menyatakan bahwa di dalam kelas kooperatif siswa belajar bersama dalam kelompok-kelompok kecil yang terdiri dari 4- 6 orang siswa yang sederajat namun heterogen, kemampuan, jenis kelamin, dan satu sama lain saling membantu. Tujuan dibentuknya kelompok tersebut adalah untuk memberikan kesempatan kepada semua siswa untuk dapat terlibat secara aktif dalam proses berpikir dan kegiatan pembelajaran.

Kemudian, guru mendemonstrasikan eksperimen yang berkaitan materi pelajaran serta membimbing siswa untuk merumuskan masalah dan melakukan eksperimen untuk menyelidiki hubungan serta mengemukakan pertanyaan dan merumuskan hipotesis. Kegiatan demonstrasi ini sangat berpengaruh positif terhadap siswa. Hal ini sejalan dengan pendapat Soetomo dalam Winarni (2018: 209) mengemukakan bahwa kelebihan demonstrasi yaitu: (1) siswa akan memperoleh gambaran yang lebih jelas mengenai proses sesuatu yang telah didemonstrasikan; (2) perhatian siswa akan lebih mudah dipusatkan pada hal-hal yang penting yang sedang dibahas, sehingga memungkinkan terjadinya proses belajar siswa yang optimal; (3) dapat mengurangi kesalahan pengertian antara siswa dengan guru karena dengan demonstrasi siswa akan dapat mengamati sendiri proses dari sesuatu; dan (4) memberikan kesempatan bagi siswa untuk mendiskusikan apa yang telah didemonstrasikan atau dapat juga melatih penguasaan atau keterampilan tertentu sebagai tindak lanjut dari demonstrasi.

Selanjutnya, siswa berdiskusi dan mengumpulkan data untuk menguji hipotesis, merumuskan hasil percobaan dan menemukan konsep. Pada tahap ini guru berperan memberikan dorongan, bimbingan, memotivasi, dan memberi arahan agar siswa dapat mengemukakan ide/pendapat yang didapat melalui kegiatan eksperimen sebagai penemuan konsep. Hal ini sejalan dengan Trianto (2007: 42) yang menyatakan bahwa di dalam kelas kooperatif siswa belajar bersama dalam kelompok-kelompok kecil yang terdiri dari 4- 6 orang siswa yang sederajat namun heterogen, kemampuan, jenis kelamin, dan satu sama lain saling membantu. Tujuan dibentuknya kelompok tersebut adalah untuk memberikan kesempatan kepada semua siswa untuk dapat terlibat secara aktif dalam proses berpikir dan kegiatan pembelajaran. Ketiga fase pembentukan konsep, pada tahap ini siswa dibimbing merumuskan hasil percobaan dan menemukan konsep dalam mengembangkan pemahaman konseptual. Kemudian, siswa bekerja sama dan berdiskusi dalam kelompok untuk merumuskan kesimpulan. Kegiatan yang dilakukan adalah siswa bekerja sama dan berdiskusi merumuskan hasil percobaan dan menemukan konsep untuk merumuskan kesimpulan atas suatu permasalahan. Hal ini diperkuat dengan hasil penelitian Anggareni, dkk (2013), Salah satu strategi pembelajaran yang memberikan kesempatan bagi siswa untuk menemukan sendiri pengetahuannya serta berperan aktif dalam pembelajaran sehingga mampu memahami konsep dengan baik dan mengembangkan kemampuan berpikir kritis adalah strategi pembelajaran inkuiri. Strategi pembelajaran inkuiri adalah suatu rangkaian kegiatan yang melibatkan kegiatan belajar secara maksimal seluruh kemampuan siswa untuk mencari dan menyelidiki secara sistematis, kritis, logis, analitis, sehingga mereka dapat merumuskan sendiri penemuannya dengan penuh percaya 


\section{Penerapan Model Inkuiri Terbimbing Untuk Meningkatkan Kemampuan Berpikir Kritis Dan Sikap Ilmiah Siswa Dalam Pembelajaran IPA Siswa Kelas V SDN 9 Bengkulu Tengah}

diri. Keempat fase aplikasi, pada tahap ini siswa maju ke depan perwakilan dari setiap kelompok yang ditunjuk untuk mempresentasikan hasil diskusi kelompok mereka masing-masing dan siswa yang lain menanggapi.

Kemudian, guru membimbing siswa untuk mentransfer dan menggunakan pengetahuan baru serta memadukannya dengan pengetahuan lain untuk memecahkan masalah nyata di dunia dengan cara melakukan diskusi secara klasikal. Kegiatan yang dilakukan adalah siswa mempresentasikan hasil diskusi kelompok sebagai konsep baru dan mentransfer dan menggunakan pengetahuan baru serta memadukannya dengan pengetahuan lain untuk memecahkan masalah. Hal ini diperkuat oleh Wena (2011: 172) bahwa diharapkan siswa tidak hanya mendengar keterangan guru tetapi dapat berperan aktif untuk menggali, menganalisis, mengevaluasi pemahamannya terhadap konsep yang dipelajari.

Pada pembelajaran yang dilakukan baik pada siklus I, siklus II, dan siklus III, guru memberikan penguatan atau motivasi. Penguatan yang dilakukan guru berupa ancungan jempol, dan memberikan penghargaan (reward) kepada kelompok yang terbaik. Kegiatan ini dilakukan agar siswa lebih termotivasi untuk memperoleh yang terbaik. Hal ini diperkuat oleh Sardiman (2016: 94) mengemukakan bahwa apabila ada siswa yang sukses dan berhasil menyelesaikan tugas dengan baik perlu diberikan pujian dengan bentuk reinforcement (penguatan) yang positif dan sekaligus merupakan motivasi yang baik sehingga akan memupuk suasana yang menyenangkan dan mempertinggi gairah belajar serta sekaligus akan membangkitkan harga diri. Hal ini diperkuat dengan penelitian Azizah, dkk (2016: 59) yang menunjukkan bahwa model pembelajaran inkuiri terbimbing dapat meningkatkan kemampuan berpikir kritis siswa pada materi energi bunyi secara signifikan dengan demikian siswa yang diberi kesempatan untuk lebih dahulu menduga hal-hal yang akan terjadi, membuktikan dugaan-dugaan yang diajukan melalui percobaan bersama kelompok, saling mengkomunikasikan hasil percobaan yang relevan dengan permasalahan yang diajukan mengakibatkan kemampuan berpikir kritis siswa dapat meningkat.

Pada fase eksplorasi, siswa dibentuk ke dalam kelompok secara heterogen, guru membagikan LKS dan menjelaskan langkahlangkah dalam mengerjakan LKS kepada setiap kelompok. Fase eksplorasi menumbuhkan sikap ilmiah siswa yaitu kreatif. Siswa bekerjasama dalam merancang suatu rencana kerja dan akan lebih mudah dan sempurna jika dilakukan dengan cara berkelompok. Dalam merencanakan pemecahan masalah siswa akan menjadi aktif dalam kelompoknya.

Pada fase pembentukan konsep, siswa dibimbing merumuskan hasil percobaan dan menemukan konsep dalam mengembangkan pemahaman konseptual. Kemudian, siswa bekerja sama dan berdiskusi dalam kelompok untuk merumuskan kesimpulan. Kegiatan yang dilakukan adalah siswa bekerja sama dan berdiskusi merumuskan hasil percobaan dan menemukan konsep untuk merumuskan kesimpulan atas suatu permasalahan. fase ini dapat menumbuhkan sikap ilmiah siswa yaitu rasa ingin tahu siswa. Hal ini diperkuat oleh hasil penelitian Santiasih, dkk (2013: 8), model inkuiri terbimbing dapat melatih dan mendorong sikap ilmiah siswa seperti sikap ingin tahu, sikap berpikir kritis, kerjasama, menghargai temuan teman, dan lain-lain. Keterlibatan siswa secara aktif baik fisik maupun mental 
dalam kegiatan eksperimen akan membawa pengaruh terhadap pembentukan pola tindakan siswa yang selalu didasarkan pada hal-hal yang bersifat ilmiah. Dengan memberikan objek baru kepada siswa akan dapat mengembangkan sikap ingin tahu siswa. Senada dengan hal tersebut Astuti, dkk (2012: 57) mengemukakan Sikap ilmiah siswa adalah sikap tertentu yang diambil dan dikembangkan oleh ilmuwan untuk mencapai hasil yang diharapkan. Sikap ilmiah siswa dapat ditingkatkan dengan menciptakan proses pembelajaran yang memungkinkan siswa dapat menggali dan meningkatkan sikap ilmiahnya. Siswa yang memiliki sikap ilmiah tinggi akan lebih mudahdalam menguasai dan menjelaskan materi kepada teman sekelompoknya, guru dan kelompok lainnya dan cenderung memiliki prestasi elajar afektif yang tinggi dan sebaliknya. Hal ini diperkuat dengan penelitian Natalina, dkk (2013: 37) yang menunjukkan bahwa penerapan strategi pembelajaran inkuiri terbimbing dapat meningkatkan sikap ilmiah (sikap ingin tahu, kerjasama, teliti, toleransi, disiplin, percaya diri, dan tanggung jawab) dan hasil belajar biologi siswa kelas VIII SMP Negeri 14 Pekanbaru Tahun Ajaran 2012/2013.

\section{Kesimpulan}

1. Penerapan model inkuiri terbimbing dapat meningkatkan aktivitas pembelajaran menjadi lebih baik, artinya terjadi peningkatan persentase skor pengamatan pada siklus I dengan kategori Cukup menjadi kategori baik pada siklus II, dan kriteria sangat baik pada siklus III.

2. Penerapan model pembelajaran inkuiri terbimbing dapat meningkatkan kemampuan berpikir kritis siswa untuk indikator memberikan penjelasan secara sederhana (memfokuskan pertanyaan), memberikan penjelasan secara sederhana (menjawab pertanyaan tentang suatu penjelasan), membangun keterampilan dasar (nilai pertimbangan dapat dipercaya atau tidak), dan menyimpulkan (membuat atau menentukan nilai pertimbangan) meningkat pada setiap siklus.

3. Penerapan model inkuiri terbimbing dapat meningkatkan sikap ilmiah siswa. Hasil analisis data untuk indikator rasa ingin tahu yang tinggi, ulet dan tidak putus asa, dan kreatif meningkat pada setiap siklus

\section{Saran}

1. Dalam model inkuiri terbimbing sebaiknya pada fase eksplorasi siswa seharusnya memperhatikan demonstrasi eksperimen yang berkaitan materi pelajaran di depan kelas dengan cara guru memfokuskan perhatian siswa sebelum melakukan demonstrasi sehingga mudah untuk memahami materi pelajaran dan pada fase aplikasi, siswa seharusnya mampu untuk mentransfer dan menggunakan pengetahuan baru serta memadukannya dengan pengetahuan lain untuk memecahkan masalah nyata di dunia dengan cara melakukan diskusi secara klasikal.

2. Pada indikator berpikir kritis yaitu indikator memberikan penjelasan secara sederhana (menjawab pertanyaan tentang suatu penjelasan) masih rendah sehingga guru dalam fase eksplorasi harus berperan memberikan dorongan, bimbingan, memotivasi, dan memberi arahan agar siswa dapat mengemukakan ide/pendapat yang didapat melalui kegiatan eksperimen sebagai penemuan konsep. 


\section{Penerapan Model Inkuiri Terbimbing Untuk Meningkatkan Kemampuan Berpikir Kritis Dan Sikap Ilmiah Siswa Dalam Pembelajaran IPA Siswa Kelas V SDN 9 \\ Bengkulu Tengah}

3. Sikap ilmiah dalam pembelajaran sudah pada kategori sangat baik hendaknya dipertahankan dengan memaksimalkan setiap langkah pembelajaran dalam fase model inkuiri terbimbing.

\section{Referensi}

Anggareni, Ristiati, Widiyanti, (2013), Implementasi strategi pembelajaran inkuiri terhadap kemampuan berpikir kritis dan pemahaman konsep IPA siswa SMP. e-Journal Program Pascasarjana Universitas Pendidikan Ganesha.

Azizah, Jayadinata, Gusrayani (2016), Pengaruh Model Pembelajaran Inkuiri Terbimbing Terhadap Kemampuan Berpikir Kritis Siswa pada Materi Energi Bunyi, Jurnal Pena Ilmiah Vol. 1 No. 1. Tersedia: http://ejournal.upi.edu/index.php/pen ailmiah/article/view/2931.

Santiasih, dkk (2013). Pengaruh ModelPembelajaran Inkuiri terbimbing terhadap Sikap Ilmiah dan Hasil Belajar IPA siswa kelas V SD No.1 Kerobokan Kecamatan Kuta utara Kabupaten Badung Tahun pelajaran 2013/2014. e-Journal Program Pascasarjana Universitas Pendidikan Ganesha Program Studi Pendidikan Dasar （Volume3Tahun2013) $\quad$ http://119.252.161.254/ejournal/index. php/jurnal_pendas/article/viewFile/51 2/304.

Suwartaya, Nugroho, Khumaedi, (2013), Pengembangan Perangkat Pembelajaran Model Inkuiri Terbimbing Berefleksi pada Materi Konduktor dan Isolator Panas. e-journal, Program Pascasarjana, Universitas Negeri Semarang, Indonesia. http://journal.unnes.ac.id/sju/index.ph p/jpe. Diunduh tanggal 13 Maret 2018.

Trianto, (2010), Mengembangkan Model Pembelajaran tematik, Jakarta: Prestasi Pustaka.

Wena, Made., (2011),Strategi Pembelajaran Inovatif Kontenporer. Jakarta : Bumi Askara.

Winarni, E. W., (2018). Pendekatan Ilmiah dalam Pembelajaran Kreatif dan Inovatif, Bengkulu: Unit Penerbitan FKIP Press.

Winarni, (2018), The Impact of Thematic Learning Integrated ICT in Tabot Bengkulu as Cultural Ceremony toward Social Interaction Knowledge in Elementary School, Asian Journal of Education and Training, Vol. 4, No. 2, 70-74, ISSN: 2519-5387.

Winarni, E. W., (2012), Inovasi pembelajaran IPA. Bengkulu, FKIP 